Rafał Gawałkiewicz

\title{
BAGRY LAKE - VOLUME 1. A BIBLIOGRAPHIC QUERY OF LITERATURE AND ARCHIVE DATA IN EXPLAINING THE EVOLUTION OF THE WATER
}

\author{
AGH University of Science and Technology in Krakow, \\ Faculty of Mining Surveying and Environmental Engineering \\ rgawal@wp.pl
}

Keywords: Bagry Lake, history of mining excavation

\begin{abstract}
In the present borders of the city of Krakow there are many post-mining pits, often called „wounds” in the landscape. They form post-exploitation troughs after the mining of: clay, sand, gravel and limestone, now filled with precipitation waters, meltdown waters and ground waters. Once mining objects, nowadays they fulfil various functions: sport and recreational, ecological and cultural, economic and educational. In terms of nature and landscape (due to the impact of natural forces functioning as an unorganized area), one of the biggest and most beautiful water bodies in the city is the Bagry Lake. Despite its localization near the strict centre of the city and belonging to the newest objects of this type (exploitation ended in 1972), the water body of Bagry has not been thoroughly inventoried so far. The combination of hydrographic data obtained by the author and bibliographic query of literature and archive data allowed us to fully illustrate the stages of the water body formation and to describe the characteristic of the borrow pit.
\end{abstract}

\section{ZALEW BAGRY - CZĘŚĆ 1. KWERENDA BIBLIOGRAFICZNA DANYCH LITERATUROWO-ARCHIWALNYCH W WYJAŚNIENIU EWOLUCJI ZBIORNIKA}

Słowa kluczowe: Zalew Bagry, historia eksploatacji górniczej

\begin{abstract}
Abstrakt
W obecnych granicach miasta Krakowa zlokalizowanych jest wiele wyrobisk pogórniczych, często nazywanych „ranami” w krajobrazie. Stanowią niecki poeksploatacyjne po złożach: gliny, piasku, żwiru, wapienia, dziś wypełnione wodami opadowymi, roztopowymi i gruntowymi. Niegdyś obiekty górnicze, w chwili obecnej pełnią wielorakie funkcje: sportowo-rekreacyjne, przyrodniczo-kulturowe, gospodarcze i edukacyjne. Jednym z największych i najpiękniejszych akwenów wodnych miasta pod względem przyrodniczo-krajobrazowym (dzięki oddziaływaniu sił przyrody), funkcjonującym jako teren nieurządzony jest Zalew Bagry. Mimo iż zlokalizowany jest w pobliżu ścisłego centrum miasta i należy do grupy najmłodszych tego typu obiektów (eksploatacja zakończona w 1972 roku), dotychczas nie doczekał się pełnej inwentaryzacji. Połączenie danych hydrograficznych, pozyskanych przez autora, oraz kwerenda bibliograficzna danych literaturowo-archiwalnych, pozwoliły na pełne zilustrowanie etapów kształtowania zbiornika oraz opis charakterystyki wyrobiska.
\end{abstract}

\section{INTRODUCTION}

The development of the city of Krakow, already in the Middle Ages depended on the supply of aggregates, necessary for construction, especially building fortifications. Also in $20^{\text {th }}$ century, the process of carrying out of many city projects, especially transportation, was based on resources mined near the construction site. It was 
due to economic calculations, i.e. minimisation of the costs of transport. Such mining activities result in many post-mining excavations localized within the borders of Krakow, making the remnants of open-cast mining of solid materials i.e.: limestone, argyles and natural aggregates: gravels and sands. Actually, they are examples of permanent landscape transformations in the form of troughs of various areas, shapes and depths, which, after being filled with ground waters and precipitation waters, became the beginning of their evolution.

The end of the exploitation and the stabilization of water balance (spontaneous liquidation of the depression funnel as soon as the waters stopped being pumped), resulted in the transformation of the areas into picturesque water bodies of exceptional ecological values (Motyka J., et al.. 2003) and aesthetic values, despite their situation in the areas under strong industrial pressure Pietrzyk-Sokulska E., (2010). Their present state (cubature, geo-morphological differentiation of the bottom, the shape of the shoreline), appearance and way of the management of the area near the water (landscape and vegetation) result from anthropo-pressure (industry) and reclamation activities, so far very limited, designed to restore the environmental equilibrium. Landscape and vegetation around the water body also result from the impact of natural forces, due to natural succession of vegetation, in great extent creating the element of the attractiveness of the landscape Pietrzyk-Sokulska E., (2015). Many of them were given new functions, often significantly increasing the environmental attractiveness of the area.

The reservoir is a no-drainage water body supplemented only by precipitation waters, melt-down waters and ground waters. It is a natural enclave of nature in the city centre, characterized by great diversity of flora and fauna as well as an example of the co-existence of various ecosystems: water, meadows (wet and anthropogenic meadows). The habitat was shaped for many years making the ecological niche for waterfowl species, today it requires legal protection. An efficient solution in the framework of preservation of such small pieces of the city area, would be granting Bagry a status of ecological utility (in Polish użytek ekologiczny) (Kudłek et al. 2005). Slowly extinguished aggregate exploitation from Bagry, left the degraded areas of huge and not fully used potential. This results from small so far financial means given by the city authorities, lack of the vision referring to the enhancing of the attractive- ness of the water body situated in a city centre (about $5 \mathrm{~km}$ from the Main Square - Rynek Główny) and the formation of the awareness of investors from a private sector and public sector for the improvement of life quality in the living environment in the aspect of sustainable development (Gradziński P., Heigel M., 2016). Unfortunately, the Bagry Lake functions as an unorganized object and, until recently it was an object hydrographically not examined, which significantly limited the change of the state of its management.

The article presents the history of the development of mining excavations in the area of Bagry Wielkie, including the characteristic of the water body and the chronology of mining activities.

\section{LOCALIZATION OF THE BAGRY RESERVOIR AND OTHER POST-MINING WATER BODIES IN KRAKOW}

Within the administrative borders of the city of Krakow there are several smaller or bigger ponds and artificial lakes located mainly in the eastern part of the city. The majority of them constitute a side effect of the mining of aggregates and clay within the terrace Wisa - Płaszów, Przewóz (Pociask-Karteczka J., 1994). The total area of post-exploitation water bodies makes only $0.44 \%$ of the total city area, where Bagry makes $0.092 \%$. The localization of the anthropogenic water bodies on the background showing the borders of the Krakow city is illustrated in figure 1.

According to the surveying data of GODGiK in Krakow, the area of the city is $32783 \mathrm{ha}$. The data in table 1 show that the total area of post-exploitation water bodies makes only $0.44 \%$ of the total city area. The localization of anthropogenic water bodies on the background of the Krakow city was illustrated in fig. 1, while basic morphometric parameters and administrative affiliation was presented in table 1.

One of such objects is the Bagry Lake (Zalew Bagry), often called “Great Bagry” (,Bagry Wielkie”), located in an industrial district of Krakow - Podgórze (district XIII) - region Płaszów (city commune of Kraków, city district), alongside the railway no. 91 destination Kraków - Medyka (initially Charles Luis Galician Railway - section Krakow - Lviv), in the neighbourhood of the rails of a big industrial spur, connecting the nearby 


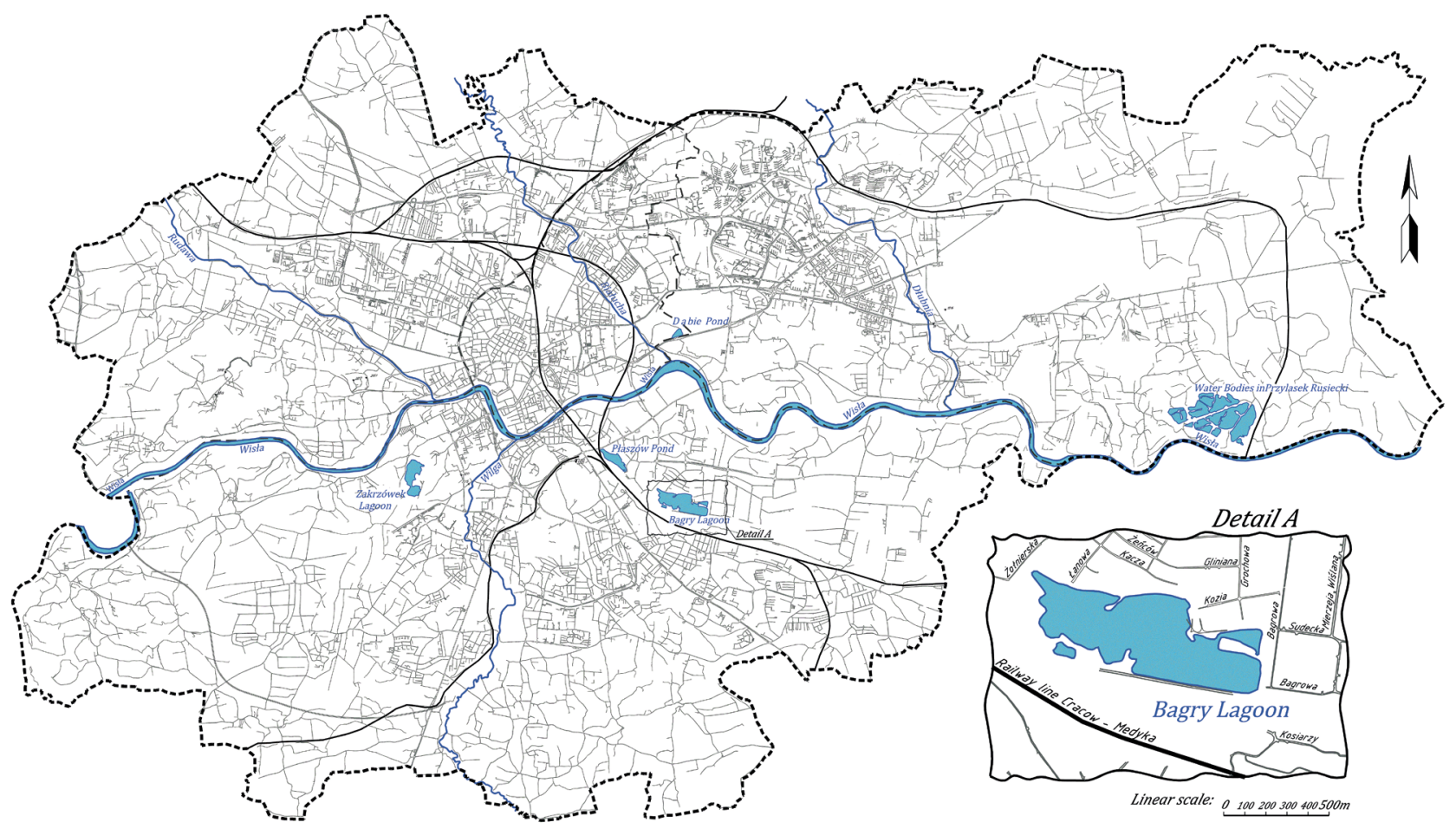

Fig. 1. Localization of anthropogenic water bodies in Krakow against the administrative borders of the city and communication routes

Rys. 1. Lokalizacja antropogenicznych zbiorników wodnych w Krakowie na tle granic administracyjnych miasta i szlaków komunikacyjnych

Table. 1. The biggest anthropogenic water bodies situated in the administrative borders of the Krakow City

Tabela 1. Największe antropogeniczne zbiorniki wodne położone w granicach administracyjnych Krakowa

\begin{tabular}{|c|c|c|c|c|c|}
\hline $\begin{array}{l}\text { Name of the } \\
\text { water body }\end{array}$ & $\begin{array}{c}\text { District } \\
\text { of Krakow }\end{array}$ & $\begin{array}{c}\text { Number } \\
\text { of } \\
\text { excavations }\end{array}$ & $\begin{array}{l}\text { Total } \\
\text { area } \\
\text { [ha] }\end{array}$ & $\begin{array}{l}\text { Percentage } \\
{[\%] \text { of the }} \\
\text { city area }\end{array}$ & Source \\
\hline Zakrzówek & Dębniki VIII & 1 & 17.0 & 0.052 & Wagner A., Hruševar D., (2015) \\
\hline Bagry & Podgórze XIII & 2 & $\begin{array}{c}22.9 \\
29.27 \\
30.27\end{array}$ & $\begin{array}{c}- \\
0.089 \\
0.092\end{array}$ & $\begin{array}{l}\text { Ogar R., Skiba M.J. (2016) } \\
\text { Pietrzyk-Sokulska E., (2010) } \\
\text { Gawałkiewicz R., (2017) }\end{array}$ \\
\hline Staw Płaszowski & Podgórze XIII & 1 & $\begin{array}{l}7.9 \\
9.24\end{array}$ & $\begin{array}{c}- \\
0.028\end{array}$ & $\begin{array}{l}\text { Budnik et al.2013 } \\
\text { Gawałkiewicz R., (1999) }\end{array}$ \\
\hline Staw Dąbski & Grzegórzki II & 1 & 2.1 & 0.006 & Wagner A., Hruševar D., (2015) \\
\hline Przylasek Rusiecki & Nowa Huta XVIII & $\begin{array}{l}11 \\
14\end{array}$ & $\begin{array}{c}82.19 \\
86.7\end{array}$ & $\begin{array}{c}0.251 \\
-\end{array}$ & $\begin{array}{l}\text { Wagner A., Hruševar D., (2015) } \\
\text { Pietrzyk-Sokulska E., (2010) }\end{array}$ \\
\hline
\end{tabular}

factories and stores and the rails of the hump in Prokocim (cargo station Krakow - Prokocim). The legal owner of the water body is the Commune of Kraków (Sutkowska M., 2013).
From the north the water body is limited by streets: Kozia, Kacza, Marian Batko and Łanowa with characteristic low buildings. From the east Bagry is closed by the Bagrowa Street making a compact industrial and 
business part of Płaszów, while from the west there is Żołnierska Street, with small allotments alongside and the fundaments of non-existing industrial halls and the areas of now non-existing Płaszów Brick and Tile Factory S.A, which was supplied by the material taken from the Bagry excavations.

\section{HISTORY OF THE BAGRY WATER BODY WRITTEN IN POLISH LITERATURE}

The origin of hydronym „Bagry” comes from German. It means exploitation of natural aggregates (gravel or sand) with an excavator or dredger (in German: Bagger). In fact, the name „Bagry” is a Polonised German word Baggersee, used in Silesia and Galicia to define artificial water bodies formed due to spontaneous filling with shallow ground waters of not working gravel, sand and clay quarries (Pietrzyk-Sokulska E., 2011; Chytkowska E., 2008; Drenda J., et al. 2011). The place of the localization of the reservoir is not accidental. Similarly as a situated in the vicinity the Płaszów Pond (Staw Płaszowski), the Bagry Reservoir is in a trough covered with the layer of the Quaternary sediments (on the Miocene layer), where sand and gravel from rivers and those of fluvio-glacial origin dominate. Based on the data analysis of the geological data of geological and engineering boreholes (source: http://bazagis.pgi. gov.pl/website/cbdg), it can be concluded that the approximate value of the thickness of these formations in the longitudinal section through the water body ranges from 8.2 to $10.1 \mathrm{~m}$. The approximate value results from the depth in the range $12.0-13.0 \mathrm{~m}$, which is not enough to reach the layers lining the beds of aggregates, i.e. the layers of Miocene loames. The volume of the water resources allows classifying Bagry in the group of the small retention objects (Biedroński J., 2005), i.e. up to 5 million $\mathrm{m}^{3}$, because the volume of resources is $1405762 \mathrm{~m}^{3}$ (state for March 2016 - the measurements by Gawałkiewicz R.).

It is located in the areas of already non-existing ponds of the oxbow lake of the Vistula River, with vast meadows, which already in 1370 , based on the Magdeburg Law were incorporated to the city of Kazimierz by king Casimir (Kazimierz) the Great. Already in those times there was a large brickyard there, the work of which depended of frequent supplies of ma- terials (Kruszyńska A., Wendel I., - www.dzielnica13. krakow.pl/o-dzielnicy). Significant resources of the Płaszów clays, loams and sands and the needs of the city caused the concentration of ceramics industry in this region. Thus, on the maps of Krakow from 1920s and 1930s it is seen that a particular role among industry was played by brickyards producing bricks and tiles, inter alia: „Płaszowianka” - Steam Factory of Bricks and Tiles Sp. z o.o. working at the street Ks. Prałata Łaczka, established in 1920 and the Płaszow Factory of Bricks and Tiles S.A, established in 1896, located in Gromadzka str. 66 (Kalendarz „Express” [3]). This was the Płaszow Factory of Bricks and Tiles S.A, localized near Bagry and stocked with aggregates coming from numerous excavations located in the area of the present water body, producing bricks: machine brick, hollow brick, chimney brick and tiles: Marseilles tiles, folded tiles and plain tiles (Księga adresowa (Address Book) 1933-1934 [1]; Przegląd budowlany [2]). Thus, one can say that the history of the water body started in $19^{\text {th }}$ century, although the exact date of the start of mining in the Bagry area is now difficult to define. In the initial stage of these activities the obtained materials were used by local brickyards (clay), while gravels made building material for the buildings in the region of Prokocim. First notes about relatively well organized mining in the area of the present Bagry come from the time of the First World War. In those times the mining was carried out by the groups of Russian prisoners of war. It can be assumed that a large part of the mined aggregates was applied in the building of large railway marshalling yard in Prokocim $(1914 \div 1916)$. During the Second World War, the occupiers enlarged the marshalling yard in the connection with attacking the Soviet Union and necessity to move large numbers of troops and equipment (Chytkowska E., 2008). The aggregates were taken from the eastern part of the present Bagry - Freight Station Kraków - Prokocim, after 1949 renamed to the Polish State Railway (Polskie Koleje Państwowe) (Niechaj M., - www.dzielnica12.krakow. $\mathrm{pl} / \mathrm{o}-$ dzielnicy/historia).

The choice of the location of the quarry was directed by the localization of significant layers of fine aggregates (gravel and sand) near the planned transportation projects and places already exploited for brickyards and the presence near the Nazi labour camp KL-Płaszów, guaranteeing cheap labour. Such a configuration stimulated the development of adjacent areas. Vast and hilly 
area of the labour camp and their vicinity required huge amount of labour at the stage of their transformation to build the death camp and the buildings of administrative and residential area for German high officials - and later on - to form the defined structure of the city. In $1942 \div$ 1945 the area of Plaszow was the biggest construction place in Krakow (Kotarba R., 2014). The implementation of the development of city infrastructure required providing the supply of materials for the construction such as stone, brick, and aggregates. Thus, in the direct neighbourhood of the camp, limestone was quarried in two quarries working for the needs of road and building industry (southern side of the Wielicka Street), clay was exploited from the Płaszow Pond to be used in ceramic production for building industry (northern side of the Wielicka Street), while fine aggregates, i.e. gravels and sands were quarried in the eastern part of the Bagry Pond. Owing to the labour of the prisoners (mainly Jewish and Polish), Germans carried out numerous construction projects in Krakow. One of such projects that made the Bagry Reservoir change its shape completely, was development of the rail junction in Krakow and adjusting communication routes within the city to the military needs in. Because it was necessary to gather a considerable number of prisoners and make it easier to manage the human resources, already in 1942, Germany made first camps of forced labour for Jews (Judenlager):

1. Julag I in Płaszow (in the area of railway barracks, located opposite of city lime kilns);

2. Julag II in Prokocim (Cmentarna Street);

3. Julag III in Bieżanow (the hamlet of Gaj).

The camps were run by the commanding officer of SS and police for the Krakow district, and in 1943 these camps were incorporated into the Płaszow camp, making their branches. Construction work in the city was carried out by German companies and supervised by the board of the railway.

The project required fine aggregates to build railway embankments and the accompanying technical objects. Due to obtaining aggregates from the Bagry Reservoir and the Płaszow Pond it was possible to build:

1. railway embankments on the rail section Płaszów - Skawina and rail viaduct over the Wielicka Street;

2. north - east by-pass line (Łobzów-Olsza-Płaszów) with the bridge over the Vistula River;
3. marshalling yard in Prokocim;

4. road infrastructure.

Exploitation in the borrow pit Bagry was carried out below the ground water table. Thus it was necessary to drain the water, which was on the bottom of the water body and the excess of water to the Vistula River. Thus, it is probable that the cartographic image of 1944 showing several small water bodies located near the narrow-gauge railway leading to the nearby brickyard did not fully reflect a real shape and the scale of works.

Exploitation in the quarry of Bagry during the Nazi occupation was carried out in the south-east, below the water table. A relatively flat bottom is observed here (maximal depth - 7.8m (Gawałkiewicz R., 2017)). The shape of the water body basin is geometrically regular (dry terrestrial exploitation). Obtaining such a regular excavation was possible due to the work of pumps, removing precipitation and ground waters from the exploitation trough to the Vistula River, which guaranteed direct access to the deposit. This explains a regular shape of the basin in this part of the water body.

After the Nazis stopped the exploitation in 1945 (retreat of their army from the Polish territory), also the process of draining stopped. Switching off the pumps on the bottom of the pit, the trough was flooded and one of then the biggest water bodies in Krakow and vicinity (Mytych D., 2011). As result, the trough quickly filled with ground waters, making the shoreline of the water body (or rather two water bodies divided by a levee - Pietrzyk-Sokulska E., 2015b) very complicated from geometrical point of view (Gawałkiewicz R., 2017). The end of exploitation was not combined with the process of reclamation, which in this case should be connected with the works levelling the bottom (modelling it). Due to this, in the publications one can find information on the attractions the explorers of this object can expect.

The lack of bathymetric measurements already in 1946 and 1947 contributed to the death of first users of the water body (documented incidents) in the east, where the exploitation had ended (Bieniarzówna J., et al. 2004). The need for aggregates in a developing postwar city such as Krakow, including the industrialization of the city (the time of so-called second industrialization of Poland), caused the reactivation of the quarrying in the west part of Bagry and significant prolongation of this water body. A historical part of the Bagry Res- 
ervoir (east side) was separated from the active part of the quarry with a wide levee, also fulfilling the transportation route for the vehicles transporting aggregates to the nearby brick factories and factories producing pre-stressed concrete for building industry (residential buildings made of panels).

On $15^{\text {th }}$ December 1951, the Krakow Enterprise for Aggregate Exploitation (Krakowskie Zakłady Eksploatacji Kruszywa - KZEK) was formed by the decision of the Minister of Shipping. However, the history of this enterprise was going back to the times before the Second World War. KZEK had supervision over 5 quarries and the Kraków Shipyard. In reality, only after the re-organization of the enterprise, in 1959-1960, in 1961 (the year of the reconstruction of the firm), full exploitation of the deposit started in the western part of the water body, where the exploitation was carried out before and during the Second World War. Geomorphology of the bottom of the water body in the north-west part is the effect of haphazard exploitation and the conditions of quarrying. In the inter-war period, in this part of the present water body, quarrying was carried out in several neighbouring pits at the same time, where precipitation waters and ground waters accumulated in the lowest points. In the post-war period, when the water balance stabilized (spontaneous inundation of the pits), there was a return of works on the industrial scale, under the water table (water exploitation - deep excavation). The liquidation of several levees separating individual fragments of the parallel situation (state of 1964 and 1965 - table 2) and the applied method of exploitation contributed to a very differetiated bottom morphology in a central and north-western part of the water body.

From the preserved cartographic works dated for 1977, one can conclude that the last area where quarrying took place was a part of the area situated in the north-east part, including the area of the present-day bay (in the neighbourhood Sailing Club „HORN”).

According to Tomczyk-Miczka E., Ogrodnik J., (2014), quarrying of sands and gravel from Bagry ended in 1972. Closing the quarry resulted from the characteristic of 1970 s, the time of rapid economic transformation, when many mining transformations of a local significance ended their activities, leaving degraded and devastated post-industrial areas. At the same time, the repairing role was taken by local and central authorities, the task of which was finding the methods of revitalization meaning the change in the function of these areas.

Table. 2. The area of the Bagry in different stages of its development

Tabela 2. Zestawienie powierzchni i geometrii Zalewu Bagry w różnych etapach jego rozwoju

\begin{tabular}{|c|c|c|c|c|}
\hline Year & $1931^{[4]}$ & $1943^{[5]}$ & $19444^{[*]}$ & $1964^{[*]}$ \\
\hline Area [ha] & 1.62 & 2.90 & 3.02 & 18.48 \\
\hline $\begin{array}{c}\text { Outlines of water } \\
\text { bodies }\end{array}$ & 8 & 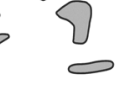 & 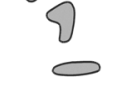 & \\
\hline Year & $1965^{[*]}$ & $1977^{[*]}$ & $19999^{[* *]}$ & $20166^{[* * *]}$ \\
\hline Area [ha] & 21.72 & 28.75 & 30.31 & 30.60 \\
\hline $\begin{array}{c}\text { Outlines of water } \\
\text { bodies }\end{array}$ & & & & \\
\hline
\end{tabular}

\footnotetext{
* - www.msip.um.krakow.pl/msip/index.html

** - based on vectorization of the basic map coming from the resources of the District Centre of Geodetic and Cartographic Documentation in Krakow of 1999.

*** - author's own work based on direct measurements (by R. Gawalkiewicz)
} 
Table. 3. Morphometrical Parameters of the Bagry Resorvoir

Tabela 3. Parametry morfometryczne Zalewu Bagry

\begin{tabular}{|c|c|c|c|c|}
\hline Parameter & Value (archive dane) & \multicolumn{3}{|c|}{ Value (state: March 2016) } \\
\hline \multirow{2}{*}{ Area of water [ha] } & \multirow{2}{*}{$\begin{array}{l}\text { 30.1 (Wagner A., Hruševar D., 2015), } \\
\text { 31.4 }^{\text {(2) }}\end{array}$} & \multirow{2}{*}{30.60} & (1) & 30.03 \\
\hline & & & 2 & 0.57 \\
\hline \multirow{2}{*}{ Length of the shoreline } & \multirow{2}{*}{ No data available } & \multirow{2}{*}{$4633 \mathrm{~m}^{(1)}$} & (1) & 4066.7 \\
\hline & & & 2 & 364.6 \\
\hline Maximal depth [m] & No data available & 7.8 & & \\
\hline Mean depth of the water body [m] & $<6^{(2)}$ & $4.66^{(4)}$ & & \\
\hline $\begin{array}{l}\text { Objętość wód części dostępnej (wg schema- } \\
\text { tu (1) w }\left[\mathrm{m}^{3}\right]\end{array}$ & No data available & 1405500 & & \\
\hline $\begin{array}{l}\text { Rzedna of the water table data measure- } \\
\text { mentu }\end{array}$ & No data available & $\frac{197.457}{21.03 .2016 r}^{(3)}$ & & \\
\hline \multicolumn{2}{|c|}{$\begin{array}{l}\text { 1. - shoreline defined based on } \mathbf{1} \mathbf{1 3 2} \text { points } \\
\text { 2. - http://www.tawernaskipperow.pl/zalew-bagry-w-krakowie, } 2384 \text {,artykul.html } \\
\text { 3. - ordinate of the water table determined in system Kronsztadt ' } 86 \\
\text { 4. - mean depth defined based on } \mathbf{7 5 3 6 6} \text { points of GRID }(2 \times 2 \mathrm{~m}) \text { generated from } \\
\quad \mathbf{6 8 0 5} \text { points measured on the shoreline bathymetric measurement }\end{array}$} & & & \\
\hline
\end{tabular}

On the turn of 1970s and 1980s, the shoreline was slightly modified in the southern part (alongside the railway). During the carried out in the neighbourhood of Bagry renovations of the railway, the water body was treated as a sort of landfill filled with industrial wastes. The polluted ballast and used reinforced concrete were thrown to the water body and covered with soil. The effect of these thoughtless activities is clearly seen from the position of boats.

Geodetic measurements made by the author in 2016, allowed the verification of morphometrical data of the Bagry Reservoir and provided more details, which was shown in table 3.

\section{PLANS OF REVITALIZATION OF THE WATER BODY IN 1972-1989}

Plans of the proper management of the areas around the water body go back the turn of 1960s and 1970s, i.e.: the time of finishing the exploitation of aggregates from its bottom. Already then the the right to manage the area of Bagry was given to the City Centre of Sport, Tourism and Leisure (Miejski Ośrodek Sportu, Turystyki i Wypoczynku-MOSTiW) „Krakowianka”. Since then many times the attempt to implement the plans of revitalization and the management of the water body and its surroundings has been made, which was written in "Dziennik Polski", among others in: 1969-1976 [6,7,9,10]. In 1972 the City Fund of Tourism and Leisure and the Department of Recreation of WSWF (the University of Physical Education), having large financial means, announced action named: „Not only Zakopane and Krynica", the purpose of which was encouraging the boards of Krakow industry to co-operation in the management of all the areas of greenery and building of large complexes in recreation centres (water and sports). According to the idea of action, the companies actively participating in the implementation of this type of realization public socially-oriented investment were supposed to look after these objects. Such a scheme of the activities of local and central government perfectly worked earlier in Szczecin and several cities in Silesia. It was also planned that this way urban and suburban water bodies in Kryspinów and Płaszów will be managed. For this purpose the Cracow 
University of Technology made full documentation for Bagry and gave it to the Krakow Enterprise for Aggregate Exploitation, which was to carry out the reclamation, according to the recommendations contained in the project. On $3^{\text {rd }}$ June 1972 the works started, only to stop after two days. Also the Municipal Enterprise for Construction Works (Miejskie Przedsiębiorstwo Robót Budowlanych, MPRB-4), which seat was in the neighbourhood of the water body, despite the promises, overhauls of the objects located on the water body were not carried out. Only owing to the Krakow Mechanic Factory of Plaster and Lime Industry Equipment (Krakowskie Zakłady Mechaniczne Sprzętu Gipsowego i Wapienniczego) the bathing zones were permanently marked.

In 1973 a big scale of the project was emphasized in press. Corrections in the management plans resulted from the acceptation of new investment programme, defining the division of the area covered by the plan, into subsequent stages of implementation. Until $15^{\text {th }}$ September 1973 , In the city plans, there was making the technical and economic premises for the management of the area planned for the localization of cubature objects [11].

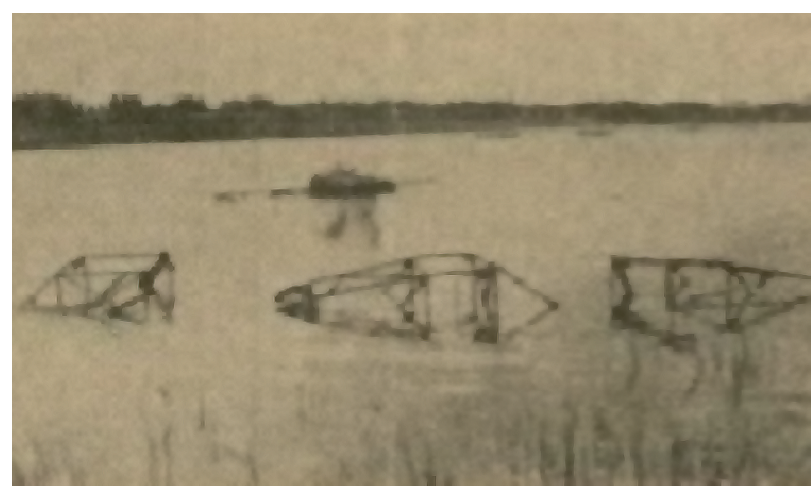

Fig. 2. The view of the fragment of the water body with the sunk remaining of mining constructions -1986 (photo: M. Kaszowski [8])

Rys. 2. Widok fragmentu zbiornika $z$ zatopionymi pozostałościami konstrukcji urządzeń pokopalnianych - 1986r (fot. M. Kaszowski [8])

In 1976 yet another time it was planned to revitalize the water body. The revitalization project of those times assumed the construction of city-quarter-managed centres on the shores of Bagry, i.e.: recreational centres and
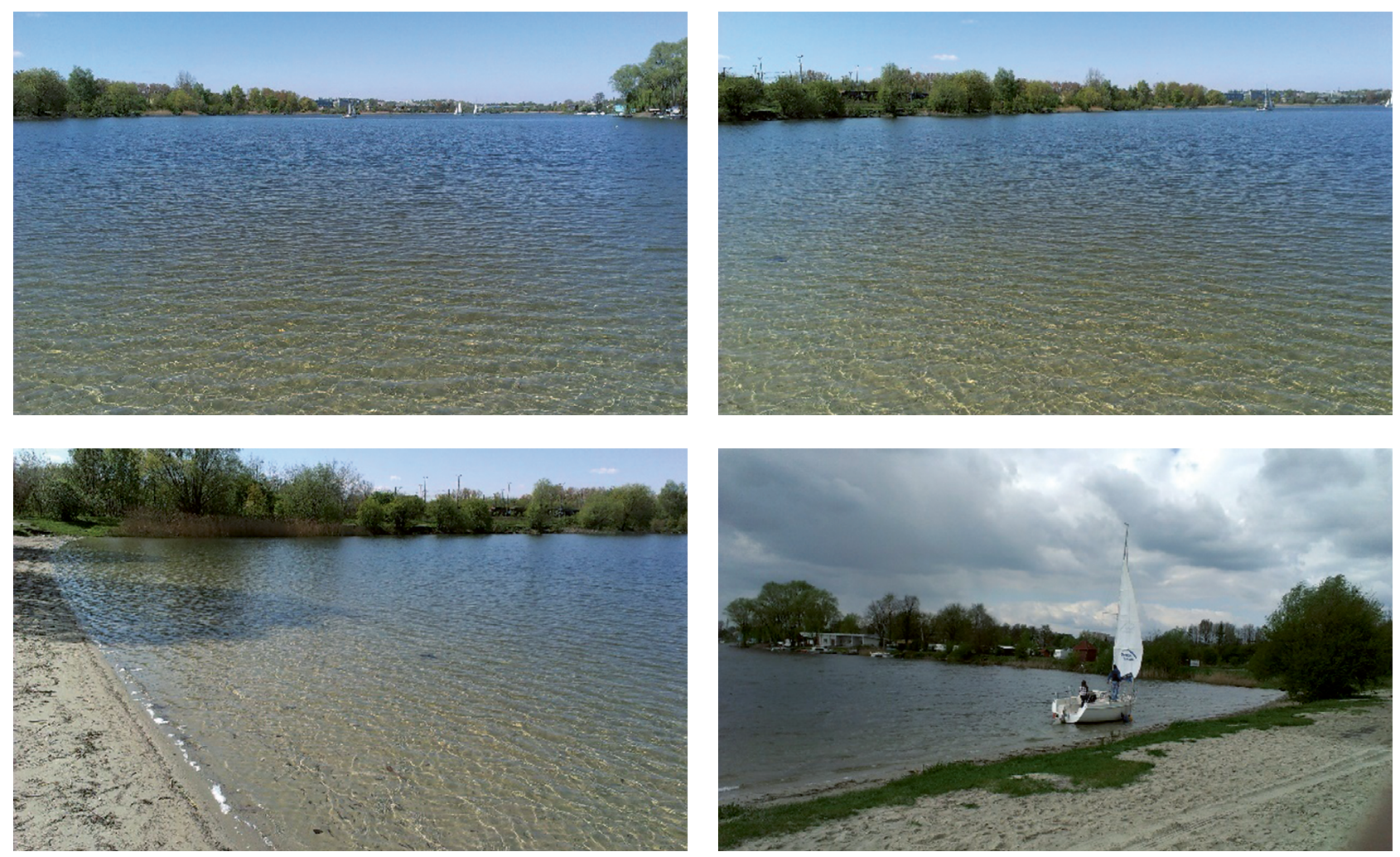

Fig. 3. Overview of the Bagry Water Body (photo: R. Gawałkiewicz)

Rys. 3. Panorama Zalewu Bagry (fot. R.Gawałkiewicz) 
water objects, as well as sports clubs [7]. The photograph (figure 2) is the graphical illustration of the press article [8]. It shows that as late as in 1986, the water body was a neglected and derelict object, where there were steel skeletons of mining constructions sticking out from the water table.

For nearly 40 years the shoreline has been preserved unchanged. Due to the effort of the local associations only alongside the northern verge of Bagry, small changes of "cosmetic" character were made. The changes made after 1986 resulted from the will to partially adjust the water body to the needs of sport and recreation. The overview of Bagry towards the north was presented in figure 3 .

\section{PLANS OF THE CITY AUTHORITIES REFERRING TO FURTHER DEVELOPMENT OF THE BAGRY RESERVOIR}

The plans of the proper management of areas around the borrow pit go back to 1960 s, i.e. the period of finishing the exploitation of aggregates from its bottom. So far none of the revitalisation projects referring to this water body has been implemented, due to the lack of funds (Szymczewska P., 2015), although the majority of the areas near Bagry belong to the city. The result of long-lasting neglects of the city authorities include lack of organization in the green areas, huge amount of rubbish floating near the shore, especially the ones overgrown with reed. Many piers were dismantled because of the bad technical state, some were replaced by floating (metal) platforms, which today do not meet standards of the safety of users. Excellent localization of the water body (of about $4 \mathrm{~km}$ from the strict city centre), well connected with the centre (two tram stops: Płaszów and Prokocim, city bus lines, the viaduct of the Nowopłaszowska Road, with the tram stops), should positively influence the revitalization process in this place.

Active for many years Association and Centres, the purpose of which is the support of social development, cultural activities, sports, educational and social activities, using water resources of the Bagry reservoir for the recreational purposes (bathing) and sports (sailing) with the representatives of local authorities (districts), try to attract the authorities' attention at the revitalisation of artificial water bodies located within the borders of the Krakow city (Bagry Wielkie, Staw Płaszowski). This interest results from excellent localization of these objects, water purity class, as well as the desire of the inhabitants and especially the lovers of water sports, for the objects of this type. A relatively large area of these water bodies is a further factor adding to the attractiveness. These objects are perfect for water sports (sailing, canoeing), also because of the already developed modern infrastructure (e.g.: AZS Yacht Club Bagry, Association „Omega” - Plaża Bagry (Bagry Beach) as well as technical and gastronomic facilities (among others "Tawerna na Hornie"). According to the plans of the city authorities, the Bagry Reservoir, with the adjacent green areas (from south - west) was, according to the Land Use Land Use Study of the Land Use for the City of Krakow, was included to a so-called zone of the management of the ecological system of the city, system of green areas and river parks to protect the ecological values of the water body, mainly fish spawning grounds and breeding places of waterfowl. This note was reflected in the Local Plan of Land Use of $11^{\text {th }}$ November 2006 [3]. This project assumed building full technical infrastructure around the water body, such as: walking paths and recreational paths alongside the water body, sanitary facilities (toilets), changing rooms, a complex of sports objects (multi-function sports fields) and car parks (Szymczewska P., 2016a). In 2008 a revitalization project of the Bagry area was made, assuming strong inference in natural environment of the water body. The proposal of a new ,look" of the object was exposed to the protests of the people living in the region of the water body (Szymczewska P., 2015). They insisted that the object should remain in the most natural form. According to the author, the residents of the area close to the water body fear the increase in the already large number of the lovers of water sports and recreation, especially in summer. It is obvious that the process of revitalizing the water body and adjacent areas would have changed Bagry. Definitely there would be many new harbours and centres of water sports, new beaches, walking paths and bicycle paths, adequately lit and monitored by proper city services, increasing this way the safety of the users at the shore and in water. Such action had a chance to bring a "second youth" to the Bagry area, and the water body itself and its surroundings would not resemble a garbage dump. Since the approval of the projects up till now, the lack of money in the city budget signifi- 
cantly limits the possibilities or even completely prevents from starting revitalization.

Today the project related to the formation of the natural environment of the water body and its surrounding is based on the development of 6 directions, i.e.: didactic and informational, bathing resort, recreational, sports, transport (communication) and leisure in the greenery. The project assumes multi-stage development of technical infrastructure (including: sanitary facilities, sports infrastructure, social infrastructure, lights), liquidation of illegal garbage deposition. It also assumes that the revitalization works will focus on a proper management of the adjacent streets so that they are fitting leisure activities. The streets are: Bagrowa, Kozia (it is planned to be rebuilt), Kacza, Batko, Łanowa, Żołnierska (east, north and west side - inter alia - construction of a north promenade running alongside the shoreline joining Batko street with the streets: Bagrowa and Grochowa) and relatively narrow area between the shoreline and railway areas from the south of the water body. In 2015 the project of the management of the Bagry reservoir, named „Safe Bathing” (Bezpieczne kapielisko) was submitted to the Citizens' Budget (Budżet Obywatelski - BO) and, due to the votes of the residents, was among the winning projects qualified for implementation. The cost is 27 million zlotys (Mrowiec M., 2016), although covers only the areas alongside the north edge of the shoreline between the streets: Kozia and Kacza to the headland situated in the neighbourhood of the Batko street. This is a revitalization of only a small fragment of the water body and its surrounding. The modernization will involve: the renovation of old lanes at the guarded beach, construction of the promenade of environmentally friendly materials (mineral and resin) alongside the shore towards the headland, construction of modern lighting and elements of small architecture (benches, dustbins), building on the meadow in the Kacza street wooden hammocks and swings as well as a mini-gym. A key element will be the stabilization of the shoreline and extensive planting of trees and bushes, ornamental grasses and water plants, which would significantly improve the aesthetics of this area. A key investment planned within the BO funds in 2016 is building of two wooden bridges, long $25 \mathrm{~m}$ and $20 \mathrm{~m}$, respectively, located in the neighbourhood of the guarded beach, i.e. alongside the Kacza street, as an equivalent to metal bridges, already dismantled due to a high degree of wearing.
So far the Great Bagry, which, together with the surrounding was in the City Plan of Management (MPZPM) was an element of the network or river parks of Krakow, can get a new image soon. The members of the City Quarter XIII intend to submit the project of the resolution of MPZPM about the formation of the Park "Zalew Bagry", which would lead to legal regulations referring to the rules of the use of the water body resources (Szymczewska P., 2016a). The idea of the Council of City District XIII is submitting the plan of the resolution on making the Parku of the Bagry Reservoir, which would generate legal regulations referring to the rules of using the resources of the water body (Szymczewska P., 2016).

\section{CONCLUSIONS}

Urban (intra-city) degraded post-mining areas are real "jewels", giving the residents chance for the development of recreational areas. Nowadays a part of such a land is very valuable, which is propagated by the Krakow developers. The Bagry Reservoir is one of anthropogenic water bodies in Poland, which is subdued to proper revitalization, management and supervision, due to its values and attractiveness of the landscape, as well as localization has a chance to obtain the status of the most popular place of leisure and recreation in the Krakow District. Such a state requires detail analysis of the designed changes with the purpose of rational use of the resources of the water bodies and adjacent areas. Over several decades a new ecosystem of increased diversity of landscape, flora and fauna was formed. Thus preservation of natural and social equilibrium requires well-thought actions, so that biodiversity can be preserved together with sustainable use of the water body for the needs of potential users. For Bagry that fulfils various functions (recreational, cultural and ecological), creating zones of landscape protection and management would be a good solution. According to the formed before 1981division (Witwicki M., 1985), the water body with adjacent areas would be classified to „K” zone (zone of the protected landscape) to increase or introduce general social functions (recreational, representation, citizens' interest, etc.), provided that the value of these areas is properly secured from destruction or deformation. After 1981 a new division of zones was made (Krupa M., 2009), based on the recommendations referring to the zones of the conservation and landscape 
management, this type of the water bodies were classified to the zone of partial protection (B). In practice the zone of partial protection (B), is marked for the area (or its fragment) and covers the areas of high cultural and natural value, where the intervention in the elements of environment is allowed, but the conservationist supervision and landscape protection is necessary. This guarantees the possibility of the implementation of many new ideas rising the attractiveness and functionality of the the water body, including the reconstruction of the old elements of infrastructure (e.g. building of piers and bridges - Szymczewska 2016a) or developing the existing tourist and leisure base without damage to the local flora and fauna in the neighbourhood. Often an obstacle in planning the process of revitalization and development of post-mining water bodies, according to the rules of sustainable use, is unsatisfactory state of knowledge on the characteristics of biosphere and geomorphology.

\section{ACKNOWLWDGEMENT}

I wish to thank Mr. Ireneusz Kaczmarek from the Association „Omega” and Mr. Radosław Jurkowski from the AZS „Bagry” for his technical support in hydrographical works.

\section{REFERENCES}

Biedroński J., (2005): Zbiorniki małej retencji - problemy funkcjonowania. W: Szponar A., Horska-Schwarz S., (red.). Struktura przestrzenno- funkcjonalna krajobrazu. Cz. II. Dynamika. Funkcjonowanie i rozwój krajobrazu. [Small retention water bodies - problems of functioning. Part II. Dynamics. Functioning and the development of landscape] Uniwersytet Wrocławski. Wrocław, pages 101-110

Bieniarzówna J., Małecki J., Chwalba A., Mitkowski J., (2004): Dzieje Krakowa: Kraków w latach 1945-1989. [The History of Krakow: Kraków in 1945-1989]. Wydawnictwo literackie, Kraków

Chytkowska E., (2008): „Bagry”, Głos Podgórza no. 3, Kraków

Drenda J., Domagała L., Różański Z., Poloczek M., Bujok A., (2011): Eksploatacja i możliwości zagospodarowania centralnego zwałowiska odpadów powęglowych Przezchlebie w gminie Zbrosławice. [Exploitation and the possibilities of the management of the central repository of coal mining wastes in Przezchlebie in the commune of Zbrosławice]. Górnictwo i Geologia, zeszyt 2, tom 6, pages 25-37

Gawałkiewicz R., (1999): Profilowanie dna zbiorników powierzchniowych i dołowych przy wykorzystaniu sondy akustycznej. Praca magisterska (niepublikowana) zrealizowana pod kierunkiem Jadwigi Maciaszek, AGH Kraków

Gradziński P., Heigel M., (2016): Architektura ekologiczna na terenach poprzemystowych, nadwodnych. [Ecological architecture in post-industrial areas situated near water] Badania i Rozwój Młodych Naukowców w Polsce, Architektura i Urbanistyka Część II, Poznań, pages 49-57

Kudłek J., Pępkowska A., Walasz K., Weiner J., (2005): Koncepcja ochrony różnorodności biotycznej miasta Krakowa. [The concept of the protection of biodiversity in Krakow City]. Instytut Nauk o Środowisku Uniwersytetu Jagiellońskiego, Kraków

Kotarba R., (2014): Niemiecki obóz w Płaszowie 1942-1945. [German concentration camp in Płaszow, 1942-1945]. Przewodnik historyczny

Krupa M., (2009): Panoramy miast zabytkowych - ochrona i kształtowanie. [Panoramas of historical city - protection and management]. Czasopismo techniczne Architektura, zeszyt 13, rok 106, Wydawnictwo Politechniki Krakowskiej, pages 79-96

Motyka J., Czop M., Polak K., (2003): Wpływ warunków wodnych w kamieniołomie Zakrzówek w Krakowie na jego funkcję rekreacyjną [,,The influence of water conditions in the Zakrzówek quarry in Krakow on its recreational function"]. Materiały Międzynarodowej Konferencji Naukowej nt. Kształtowanie krajobrazu terenów poeksploatacyjnych w górnictwie. 10-12 grudnia, Kraków, pages 208-219

Mrowiec M., (2016): Obywatelskie odmienianie Zalewu Bagry [Converting the Bagry reservoir by the citizens]. Dziennik Polski z dnia 19 lipca 2016, nr 167, Rok LXXII, Kraków

Mytych D., (2011): Przestrzeń rekreacyjna w mieście - rewitalizacja Zalewu Bagry w Krakowie [Recreational space in the city - revitalization of the Bagry Reservoir in Krakow]. Czasopismo: Przestrzeń i Forma, Wydawnictwo: Szczecińska Fundacja Edukacji i Rozwoju Addytywnego „Sfera”, tom 16, pages 515-534

Pietrzyk-Sokulska E., (2010): Zbiorniki wodne w wyrobiskach pogórniczych - nowy element atrakcyjności krajobrazu miasta" [Water bodies in post-mining excavations - new element of the city attractiveness]. Krajobraz a turystyka, Prace Komisji Krajobrazu Kulturowego nr 14, Komisja Krajobrazu Kulturowego PTG, Sosnowiec, pages 264-272

Pietrzyk-Sokulska E., 2011: Zbiorniki wodne w województwie małopolskim jako istotny element jakości środowiska. cz. 2 Charakterystyka wybranych, antropogenicznych zbiorników województwa małopolskiego. [Characteristic of selected anthropogenic water bodies of the Zeszyty Naukowe Instytutu Gospodarki Surowcami Mineralnymi i Energią Polskiej Akademii Nauk, nr 80, pages 37-65

Pietrzyk-Sokulska E., (2015a): Zbiorniki wodne w kamieniołomach jako nowy element krajobrazu [Water bodies in quarries as a new element of landscape]. Przegląd Geologiczny, vol. 63, nr 8, pages 464-469

Pietrzyk-Sokulska E., (2015b): Krajobraz poprzemysłowy w Krakowie jako efekt procesu rewitalizacji. Miasto centrum inteligentnych rozwiązań [Post-industrial landscape in Krakow as an element of revitalization process. City as 
a centre of smart solutions], Małopolskie Studia Regionalne nr 1-2/33-34/2015, Departament Polityki Regionalnej Urząd Marszałkowski Województwa Małopolskiego, pages $33-40$

Pociask-Karteczka J., (1994): „Przemiany stosunków wodnych na obszarze Krakowa". Zeszyty Naukowe Uniwersytetu Jagiellońskiego MCXLIV. Prace Geograficzne z. 96, pages 1-38

Sułkowska M., 2013: Rewitalizacja zdegradowanego miejskiego obszaru peryferyjnego o walorach krajobrazowych (Rewitalization of destroyed civic suburbs area with landscape merits). Space \& Form, no. 20, pages 407-420

Szymczewska P., (2015): Bagry, czyli jak się marnuje potencjał największego akwenu Krakowa. [Bagry - how the potential of the biggest Krakow water body is being lost], Dziennik Polski z dnia 22 kwietnia 2015, Kraków

Szymczewska P., (2016a): Tereny zielone nad Bagrami wypięknieją dzięki mieszkańcom [Greennery areas on Bagry will become more beautiful owing to the residents]. Dziennik Polski z dnia 25 kwietnia 2015, nr 96, Rok LXXII, Kraków

Szymczewska P., (2016b): Regulamin dla Bagrów: wreszcie koniec samowolki [Regulations for Bagry: at last the disorder is ended]. Dziennik Polski z dnia 18 sierpnia 2016, nr 195, Rok LXXII, Kraków

Wagner A., Hruševar D., (2015): Plant Diversity in the Area of Water Bodies near Kraków. Focus on Invasive Plants. IARIA, BIONATURE, dok.elektroniczny:

https://www.thinkmind.org/index.php?view=instance\&instance=BIONATURE+2015 [25.01.2016]

Witwicki M., (1985): Strefy ochrony konserwatorskiej: cechy obszarów chronionych, wyznaczenie granic ochrony, podstawowe wytyczne konserwatorskie. [Conservationist protection zones: the features of the protected areas, basic recommendations by the conservator]. Ochrona Zabytków nr 38/3-4. Warszawa, pages 151-156

\section{Akty prawne, opracowania specjalne [Legal Acts, Special Publications]}

[1] Księga adresowa miasta Krakowa i województwa krakowskiego z informatorem miasta Warszawy, województwa kieleckiego i śląskiego - rocznik 1933-1934 [Address book of the Krakow and the Krakow voivodship with the guide of the city of Warsaw, Kielce voivodeship and Silesian voivodeship - 1933-1934, Drukarnia Przemysłowa ul/ Józefa Sarego 7, Redakcja i administracja - ul. Mikołajska 32, Kraków

[2] Przegląd budowlany - Organ Stowarzyszenia Zawodowego Przemysłowców Budowlanych R.P. [Construction review - the Official Publication of the Profesional Society of Building Industry of the Republic of Poland], year X, no. 12, Warszawa 1938

[3] Kalendarz „Express” - Notatnik Informator na rok 1939. [Calendar „Express”- Notebook - Information Bulletin for the year 1939] Dziennik „Express Lubelski i Wołyński”, Lublin 1939

[4] Wojskowy Instytut Geograficzny - mapa topograficzna w skali 1:25000, [Military Geographic Institute - topographic map, 1:25000 scale], Warszawa 1936

[5] Town Plans of Poland - Kraków; Photolithographed by the War Office 1943, Drawn by Geographical Section, Polish General Staff $N^{\circ} 4435$

[6] Nie tylko Zakopane i Krynica [Not only Zakopane and Krynica] Dziennik Polski nr 147, Rok XXVIII z dnia 22.VII.1972 r. Wydawnictwo Prasowe RSW Kraków, page 9

[7] Wypoczynek dla krakowian [Leisure of the people of Cracow]. Dziennik Polski nr 178, Rok XXXII z dnia 6-8. VIII.1978r. Wydawnictwo Prasowe RSW Kraków, page 9

[8] Kryspinów i Bagry potrzebują lepszego gospodarza [Kryspinów and Bagry need better host]. Dziennik Polski nr 150, Rok XLII z dnia 30.VI.1986r. Wydawnictwo Prasowe RSW Kraków, page 6

[9] Sport i turystyka [Sports and tourism]. Dziennik Polski nr 105, Rok XXV z dnia 4-5.V.1969r. Wydawnictwo Prasowe RSW Kraków, page 4

[10] Nad krakowskimi akwenami [Over the Krakow waters]. Dziennik Polski nr 140, Rok XXXII z dnia 21.VI.1976 r. Wydawnictwo Prasowe RSW Kraków, page 4

[11] Kąpielisko Bagry - bez opóźnień [Bagry Bathing Center - without delays]. Dziennik Polski nr 35, Rok XXIX z dnia 10.II.1973r. Wydawnictwo Prasowe RSW Kraków, page 4 